\title{
Toll-like receptor signaling in hen ovarian granulosa cells is dependent on stage of follicle maturation
}

\author{
Dori C Woods $^{1,2}$, Jeffrey S Schorey ${ }^{1}$ and A L Johnson ${ }^{1}$ \\ ${ }^{1}$ Department of Biological Sciences and the Walther Cancer Research Center, The University of Notre Dame, \\ PO Box 369, Notre Dame, Indiana 46556, USA and ${ }^{2}$ Vincent Center for Reproductive Biology, Vincent Obstetrics and \\ Gynecology Service, Massachusetts General Hospital/Harvard Medical School, Boston, Massachusetts 02114, USA
}

Correspondence should be addressed to D C Woods is at Vincent Center for Reproductive Biology, Vincent Obstetrics and Gynecology Service, Massachusetts General Hospital/Harvard Medical School; Email: dwoods2@partners.org

\begin{abstract}
The recent identification of toll-like receptor (TLR) signaling within ovarian granulosa cells has broad implications for ovarian physiology. Functions of TLRs within granulosa cells of the laying hen are of particular interest due to the method of transovarian transmission of Salmonella enteritidis, which results in egg contamination. This study utilized hen granulosa cells to evaluate the expression and function of Gallus TLR-signaling at distinct stages of follicular maturity. Data presented herein demonstrate the presence of TLR2, TLR4, and TLR15 mRNAs in undifferentiated granulosa cells from prehierarchal follicles and differentiated granulosa cells from preovulatory follicles, together with mRNAs encoding adaptor proteins and signaling components required for TLR signaling gene. Treatment with lipopolysaccharide (LPS) or LH, in vitro, led to the differential regulation of TLRs based on the stage of follicle maturation, with the largest (F1) follicle granulosa cells having the most rapid response. Furthermore, treatment with LPS resulted in attenuation of agonistinduced progesterone synthesis in undifferentiated, but not differentiated, granulosa cells. Additionally, undifferentiated granulosa cells were significantly more sensitive to LPS-induced apoptosis than differentiated granulosa cells from the F1 follicle. Together, these data provide evidence for a complete and functional TLR signaling pathway in hen granulosa cells, with effects on steroidogenesis and cell viability dependent upon stage of maturation. These differences may reflect the susceptibility of granulosa cells at early stages of maturation to undergo apoptosis in response to select pathogenic stimuli, thus attenuating transovarian transmission, whereas granulosa cells from preovulatory follicles are comparably resistant to LPS-mediated apoptosis.

Reproduction (2009) 137 987-996
\end{abstract}

\section{Introduction}

Toll-like receptor (TLR) pattern recognition receptors (PRRs) in vertebrate species are a key component in the distinction of self from non-self, and are indispensable for the innate immune response. Activation of TLR signaling occurs following recognition and interaction with specific conserved small molecular sequences found on the surface of invading pathogens, termed pathogen-associated molecular patterns (PAMPs). PAMPs include lipopolysaccharide (LPS) associated with the cell wall of gram-negative bacteria (including Salmonella enteritidis), lipoteichoic acid associated with the surface adhesion amphiphile from gram-positive bacteria, bacterial flagellin, peptidoglycan, and components associated with viruses such as double-stranded RNA. In addition to the recognition of pathogenic stimuli, TLRs (particularly TLR2 and -4) recognize endogenous ligands. Most notably, these include extracellular matrix components, such as hyaluronan fragments, heparan sulfate, fibrinogen, fibronectin, lung surfactant protein A, and high-mobility group box 1 proteins (Zhang \& Schluesener 2006). Following ligand binding, TLR signaling can result in up-regulation of pro-inflammatory cytokines (e.g. interleukin (IL)-1B, tumor necrosis factor (TNF)), up-regulation, and facilitation of scavenger receptors, which result in the phagocytosis of pathogens, and presentation of antigen to naïve T-cells, providing a critical link to the acquired (i.e. adaptive) immune response (Medzhitov et al. 1997, Takeda \& Akira 2005). Moreover, multiple reports of TLRs in non-immune tissues have begun to surface, bringing to light non-immune-related functions of these PRRs (Liu et al. 2008).

Specifically, recent reports have implied a role for TLR signaling in the regulation of vertebrate ovarian function (Shimada et al. 2006, 2008, Herath et al. 2007, Subdei et al. 2007, Liu et al. 2008). TLRs have been identified in ovarian cells from multiple species (murine, bovine, chicken), and have been shown in bovine and murine granulosa cells to functionally mediate steroidogenesis and pathogen phagocytosis respectively 
(Herath et al. 2007, Shimada et al. 2006). Importantly, in bovine granulosa cells, TLR signaling has been shown to perturb steroidogenesis, a potential mechanism to curb ovarian follicle growth during bacterial infection (Herath et al. 2007).

Understanding the immune response in the ovary is of importance in the laying hen, as egg contamination by $S$. enteritidis represents a serious human health concern. Over $75 \%$ of $S$. enteritidis outbreaks are attributable to eggs or egg-based products (Braden 2006). The method of transmission to eggs occurs in the intraovarian environment through selective infection of the granulosa cell layer (Gast \& Beard 1990, Thiagarajan et al. 1994). Subsequent transovarian transmission to offspring results in the spread of $S$. enteritidis, through the production of contaminated eggs and fecal matter. Given the pivotal role of the granulosa layer in maintaining follicle viability and promoting maturation, as well as in propagating transovarian $S$. enteritidis transmission in the hen, identification of key signaling pathways that can contribute to ovarian function, or curb infected follicle development, are of significant interest.

While much remains to be learned about the role for TLR signaling in the ovary, it is becoming clear that TLRs expressed on granulosa cells can and do respond to both exogenous (i.e. pathogenic) and endogenous (e.g. extracellular matrix components) stimuli (Liu et al. 2008). Additional evidence from mammals suggests a role for TLR signaling in granulosa or cumulus cells both pre- and post-ovulation (Herath et al. 2007, Shimada et al. 2007, 2008). Although the significance for TLR signaling during both of these distinct phases remains to be fully elucidated, hen granulosa cells from preovulatory follicles remain within the follicle after ovulation. Thus, the mechanisms by which TLR signaling may participate in reproduction or confer immunity to the ovulated oocyte are likely to differ between avian and mammalian species.

The studies presented herein utilize both differentiated and undifferentiated hen granulosa cells as a model system to evaluate the effects of TLR signaling on granulosa cell function and viability. Accordingly, we provide evidence for 1 ) expression of TLRs and related downstream signaling component mRNAs in both undifferentiated and differentiated granulosa cells; 2) differential regulation of TLRs in granulosa cells based upon stage of maturation; and 3) a role for TLR signaling in regulation of granulosa cell steroidogenesis and viability.

\section{Results \\ PCR amplification of TLRs and signaling components in granulosa cells}

PCR amplification revealed expression of Gallus orthologs to the mammalian TLR2 (type 2), TLR4, and TLR15, in granulosa cells from prehierarchal (3-8 $\mathrm{mm}$ diameter) and preovulatory (F1) follicles, plus bone marrow.
Additionally, critical downstream signaling components and adaptor proteins are expressed in both prehierarchal and preovulatory granulosa cells, with the notable exception of MAP3K7IP1, which was amplified only in bone marrow (Fig. 1). While IL-1 receptor-associated kinase (IRAK) 2 and 4 were amplified, a Gallus homolog to IRAK1 has not yet been identified experimentally or in silico.

\section{TLR2 and TLR4 $m R N A$ expression is increased following treatment with $L H$ or LPS}

Treatment with LPS or LH for $4 \mathrm{~h}$ led to an increase in TLR2 and TLR4 mRNAs in granulosa cells from the largest preovulatory (F1) follicle (Fig. 2A), while the same culture conditions in granulosa cells from the second largest F2 follicle failed to induce a significant increase (Fig. 2B). However, TLR2 and TLR4 mRNA levels were elevated in granulosa cells from F2 follicles following treatment with LPS for $20 \mathrm{~h}$. Neither TLR2 nor TLR4 mRNA was increased in granulosa cells isolated from prehierarchal (3-8 $\mathrm{mm}$ diameter) follicles, although there was a significant decrease in TLR4 mRNA following treatment with LPS for $20 \mathrm{~h}$ (Fig. 2C).

\section{Effects of LPS on granulosa cell steroidogenesis are stage of development dependent}

To investigate whether TLR signaling modulates steroidogenesis based on stage of development, progesterone production from cultured granulosa cells was measured following a 4- or 20-h culture in the presence or absence of gonadotropin or 8-bromoadenosine 3', 5'-cyclic monophosphate (8-br-cAMP), with or without LPS $(10 \mu \mathrm{g} / \mathrm{ml})$. Treatment with LPS attenuated FSH-induced progesterone in granulosa cells from prehierarchal (3-8 mm) follicles following $20 \mathrm{~h}$ in culture (Fig. 3A). The attenuation was reversed following co-culture with U0126, a pharmacologic inhibitor of the MAPK signaling pathway, and an additive effect of FSH+LPS with U0126 was observed. Notably, treatment with LPS had no measurable effect on $\mathrm{LH}$-induced progesterone synthesis in granulosa cells from preovulatory ( $\mathrm{F} 2$ and F1) follicles following 4-h incubation (Fig. 3B and C).

\section{Sensitivity to LPS-induced cell death is dependent on stage of development}

Treatment with LPS resulted in a significant decrease in cell density following $20 \mathrm{~h}$ in culture in granulosa cells from prehierarchal (3-8 mm diameter) and preovulatory (F1) follicles. This was mediated in part by LPS-induced apoptosis, and indicated qualitatively by the presence of low molecular weight oligonucleosome formation (Fig. 4A and B). The effect of LPS was related to follicle size. 

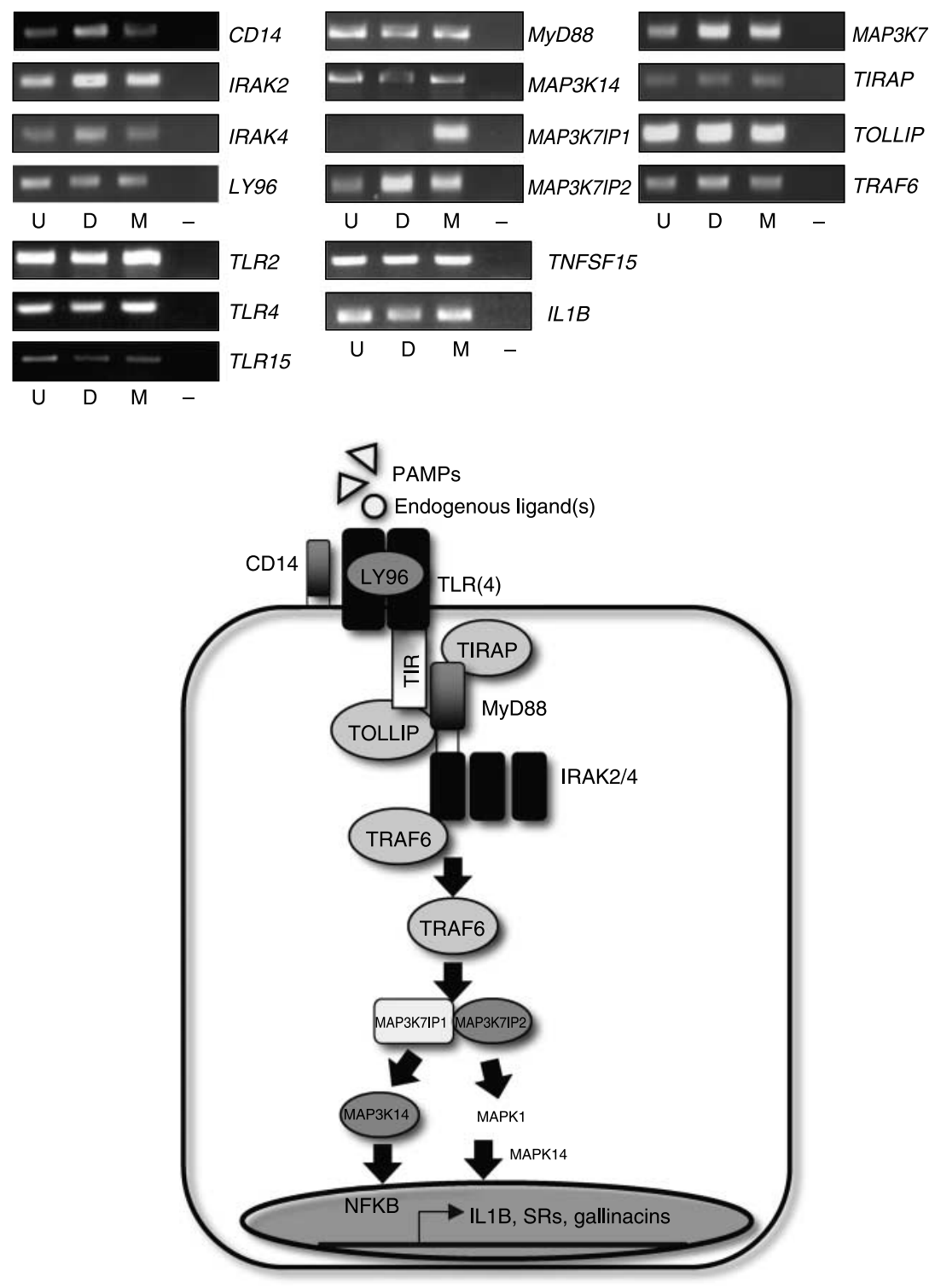

Figure 1 PCR amplification of TLRs and downstream signaling component mRNAs from undifferentiated $(\mathrm{U})$ and differentiated (D) granulosa cells. Bone marrow $(M)$ was included as a reference tissue. -, negative control (no template). Based upon expression of requisite signaling proteins, the model depicts proposed Gallus TLR signaling in granulosa cells. PAMPs or endogenous ligands bind to a TLR complex (TLR4 depicted). TLR4 is unique among TLRs, as it forms a complex with the co-receptors CD14 and MD2 at the cell surface. Subsequent to ligand activation, toll-interacting protein, TIR-domain-containing adaptor protein, and myeloid differentiation primary-response protein 88 are recruited to the cytosolic TIR domain of the receptor complexes. Following recruitment, a signaling complex comprised of interleukin-1 receptorassociated kinase (IRAK) 2 and 4 , as well as the cytoplasmic adaptor, TRAF6, is formed. TRAF6 then dissociates from the complex, activating MAP3K7 and MAP3K7IP2, resulting in the commencement of downstream signaling cascades, such as NFKB and MAPK1/MAPK, and subsequent transcription of target genes.

In prehierarchal follicle granulosa cells, a significant loss of viable cells was detected following treatment with $5 \mu \mathrm{g} / \mathrm{ml}$ LPS (Fig. 4A). However, in fully differentiated granulosa cells from $\mathrm{F} 1$ follicles, a significant reduction in granulosa cell viability occurred following treatment with $10 \mu \mathrm{g} / \mathrm{ml}$ LPS (Fig. 4B).

\section{LPS-induced cell death is caspase-8 dependent}

Following pre-treatment with the caspase-8 inhibitor, Z-IETD-FMK $(10 \mu \mathrm{M})$, the decrease in cell viability promoted by LPS was significantly reduced in granulosa cells from prehierarchal follicles, and completely reversed in granulosa cells from preovulatory (F1) follicles (Fig. 5A and B). These data indicate the activation of an extrinsic mechanism for induction of cell death, as caspase- 8 activation is death-receptor mediated. This is likely due to an increase in cytokine production by granulosa cells following treatment with LPS. To investigate potential cytokines known to be responsive to LPS or to increase cell death in granulosa cells, gene expression analysis was used to monitor the levels of TNF apoptosis-inducing ligand (TNFSF10), tumor necrosis super-family member 15 (TNFSF15), and ILIB mRNA following stimulation with LPS for $4 \mathrm{~h}$ ( $\mathrm{F} 1$ granulosa) or $20 \mathrm{~h}$ (3-8 mm granulosa). Both TNFSF10 and TNFSF15 belong to the TNF ligand superfamily, and have previously been shown to have cytotoxic effects on chicken granulosa cells, in vitro (Takimoto et al. 2005, Johnson et al. 2007). While levels of ILIB were significantly increased in granulosa cells from $\mathrm{F} 1$ follicles following a 4-h challenge with LPS, levels 

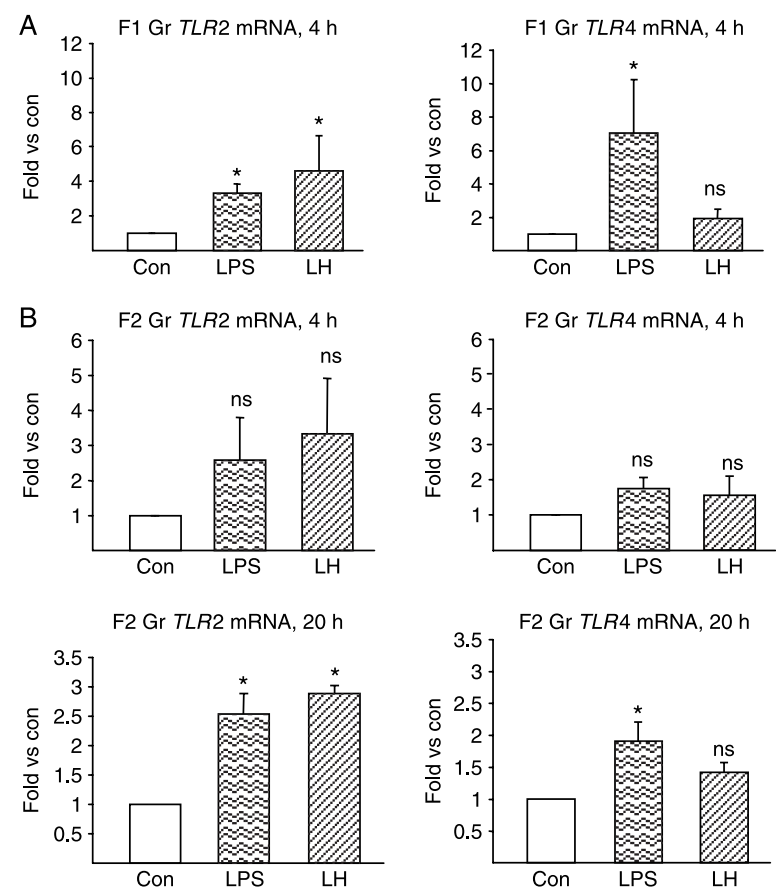

C $\quad 3-8 \mathrm{~mm}$ Gr TLR2 mRNA, $20 \mathrm{~h}$
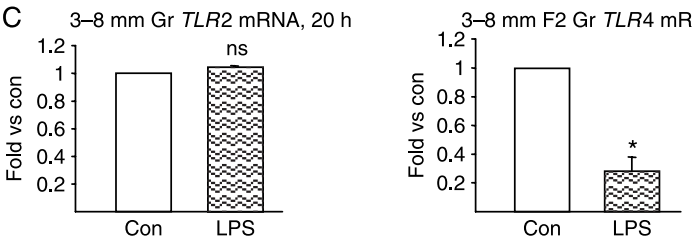

Figure 2 Regulation of TLR mRNA in differentiated (F1 and F2) and undifferentiated (3-8 mm) follicles. (A) Treatment with LPS $(10 \mu \mathrm{g} / \mathrm{ml})$ or LH $(100 \mathrm{ng} / \mathrm{ml})$ in F1 granulosa for $4 \mathrm{~h} . n=3$. (B) Treatment with LPS or LH in F2 granulosa cells for 4 or $20 \mathrm{~h}$. $n=4$. (C) Treatment with LPS in undifferentiated granulosa cells for 20 h. $n=3 .{ }^{*}$ Indicates significance $(P<0.05)$, not significant (ns; $P>0.05)$ by independent $t$-tests, for the treatment group compared with control cultured cells.

were unchanged in granulosa cells from prehierarchal follicles (Fig. 6A and B). By comparison, TNFSF10 and TNFSF15 mRNA levels in granulosa cells were not altered by LPS treatment at either stage of differentiation (data not shown).

\section{Discussion}

Thus far, 10 Gallus TLRs have been identified, including: TLR1 and TLR2 (types 1 and 2), TLR3, TLR4, TLR5, TLR7, TLR15, and TLR21. With the exception of TLR 1 and 15, each Gallus TLR has a mammalian ortholog, with TLR1 sharing significant homology to mammalian TLR1, -6, and -10 (Lynn et al. 2003). Genes for the two types of chicken TLR1 are on chromosome 1, while the genes for the two types of TLR2 are located on chromosome 4, and are thought to be the products of gene duplication (Fukui et al. 2001, Temperly et al. 2008). Additionally, in silico analysis has revealed Gallus homologs to downstream adaptor and signaling molecules, including myeloid differentiation primary-response protein 88 (MyD88), TIR-domain-containing adaptor protein (TIRAP, or MAL), toll-interacting protein (TOLLIP), IRAK4, transforming growth factor- $\beta$ activated kinase (MAP3K7), the Tak-1 binding proteins (MAP3K7IP1 and MAP3K7IP2), TNF receptor-associated factor 6 (TRAF6), and NFKB inducing kinase (MAP3K14; Lynn et al. 2003). Functional
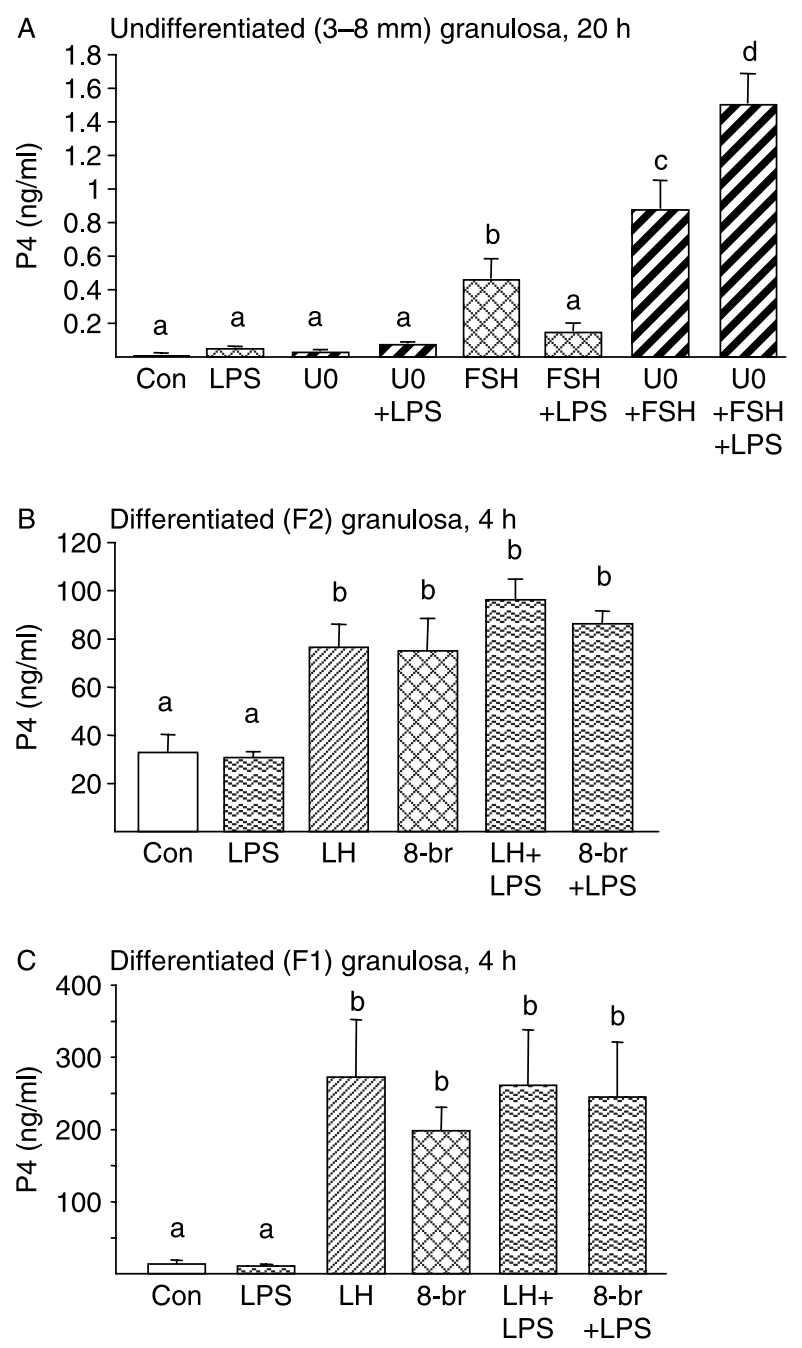

Figure 3 LPS inhibits agonist-induced progesterone (P4) from undifferentiated, but not differentiated, granulosa cells via MAPK signaling. (A) RIA targeting progesterone production by undifferentiated granulosa cells. Treatment with LPS $(10 \mu \mathrm{g} / \mathrm{ml})$ attenuates FSH $(100 \mathrm{ng} / \mathrm{ml})$-induced progesterone production. Pre-treatment with the MAP3K2/MAPK inhibitor, U0126 (U0; $10 \mu \mathrm{M})$ for $1 \mathrm{~h}$ reverses the effect of LPS treatment. $n=4, P<0.05, \mathrm{a}, \mathrm{b}$ and $\mathrm{c}$ indicate significant differences by ANOVA. (B and C) RIA targeting progesterone production from differentiated granulosa cells from the F2 (B) and F1 (C) follicle. LPS does not effect progesterone production induced by LH $(100 \mathrm{ng} / \mathrm{ml})$ or 8-br-cAMP (8-br; $100 \mathrm{nM}) . n=3, P<0.05$, a and b indicate significance. Note difference in magnitude of $\mathrm{P} 4$ for each stage of development. 

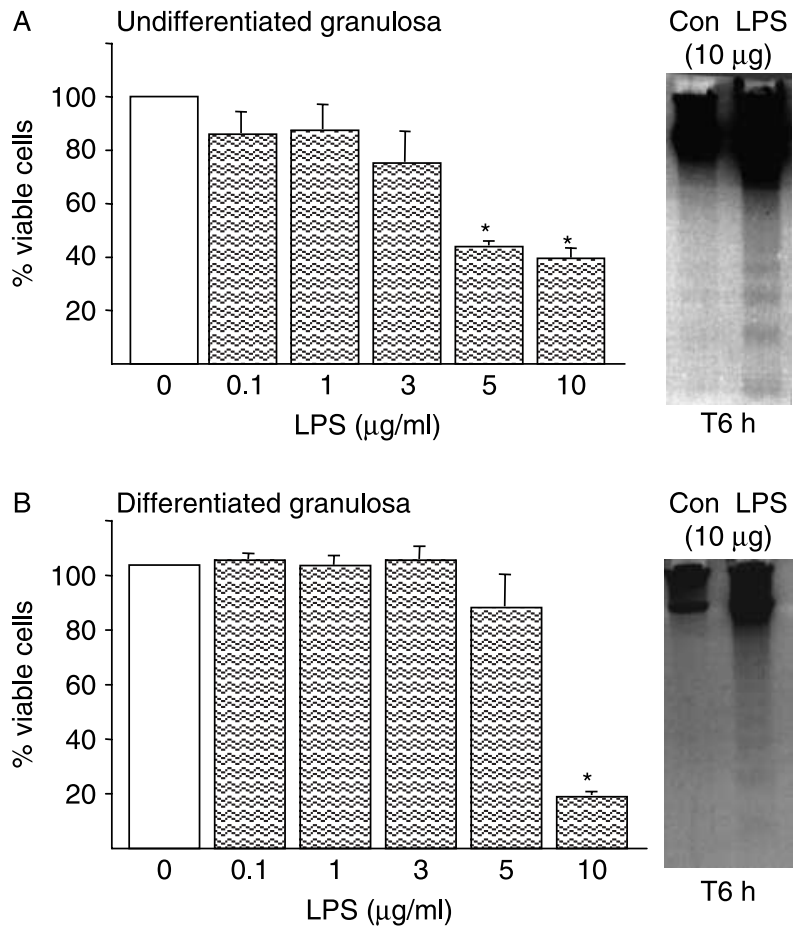

Figure 4 LPS induces granulosa cell apoptosis. (A) Cell viability assay following $20 \mathrm{~h}$ of treatment with LPS in undifferentiated granulosa cells $n=3, *$ indicates significance $(P<0.05)$. The presence of cleaved DNA fragments after a $6 \mathrm{~h}$ culture confirms activation of apoptosis. (B) Cell viability assay following $20 \mathrm{~h}$ of treatment with LPS in differentiated granulosa cells ( $\mathrm{F} 1$ follicle). $n=3, *$ indicates significance $(P<0.05$ by ANOVA).

studies on chicken TLRs demonstrate that the pathways and ligand specificity for each TLR are conserved in the hen (Fukui et al. 2001, Leveque et al. 2003, Iqbal et al. 2005, Philbin et al. 2005).

Results reported herein demonstrate the expression of mRNA encoding TLRs and key signaling components in both undifferentiated and differentiated granulosa cells from hen ovarian follicles. Multiple TLRs have been recently described in hen follicles (including the granulosa layer (Subdei et al. 2007)), and it has been postulated that TLR-mediated immune responses may participate in the protection of ovarian tissues from invasive pathogens (Shimada et al. 2006, Herath et al. 2007). Unlike a previous report that indicates the presence of only TLR4 and TLR5 in hen granulosa cells (Subdei et al. 2007), TLR4, TLR2, and TLR15 mRNAs were detected in both undifferentiated and differentiated granulosa cells from hen follicles. This finding is significant, because TLR4 and TLR2 (type 2) have been shown to recognize bacterial LPS (Fukui et al. 2001, Spiller et al. 2007). Additionally, while genes encoding key chicken TLR-signaling components have been identified in silico, this is the first study to verify their presence in granulosa cells. These data, in combination with the ability of LPS to modulate granulosa cell function, establish a functional TLR signaling pathway in hen granulosa cells.

Not surprising was the ability of LPS to modulate TLR2 and TLR4 mRNA expression levels in vitro. Similar to the results obtained from F3 (third largest preovulatory follicle), granulosa layers extracted from hens treated intravenously with LPS (Subdei et al. 2007), both TLR2 and TLR4 mRNA expressions were increased following treatment with LPS for $20 \mathrm{~h}$, but not at the earlier time point of $4 \mathrm{~h}$. The timing of up-regulation, however, differed for the largest (F1) preovulatory follicle, in which treatment with LPS elicited a significant increase in TLR2 and TLR4 mRNA levels after only $4 \mathrm{~h}$. These data suggest a differential sensitivity to LPS-induced $T L R$ mRNA based on stage of maturation, whereby an accelerated response is elicited in the follicle next to be ovulated.

This differential sensitivity also occurred following treatment with $\mathrm{LH}$. Treatment with $\mathrm{LH}$ led to a rapid (within $4 \mathrm{~h}$ ) increase in TLR2 mRNA in granulosa cells from the largest preovulatory follicle, in contrast to granulosa cells from the second largest preovulatory follicle in which the increase in TLR2 mRNA occurred later (within $20 \mathrm{~h}$ ). This finding is not entirely unexpected, due to the significant increase in $\mathrm{LH}$ responsiveness in the F1 follicle as compared with all other stages of

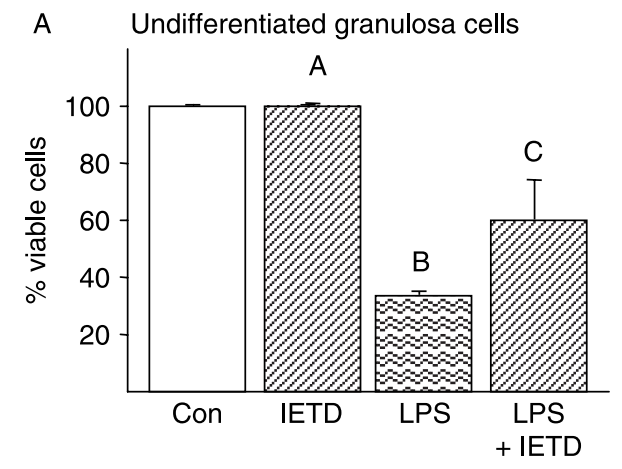

B Differentiated granulosa cells

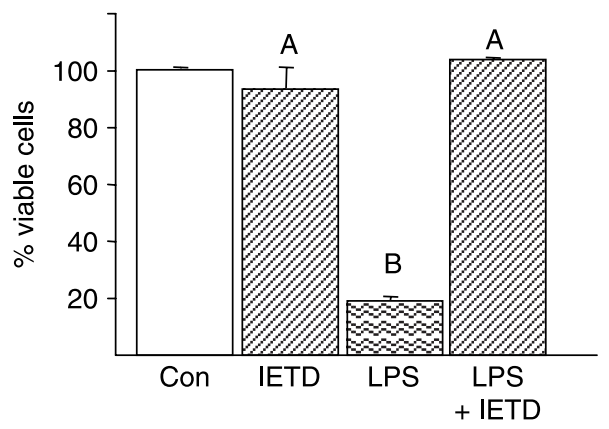

Figure 5 Inhibition of caspase-8 cleavage inhibits LPS-induced apoptosis. Cell viability assay in undifferentiated (A) or differentiated (B; from F1 follicle) granulosa cells. Cells were treated with or without Z-IETD-FMK (IETD; $20 \mu \mathrm{M}$ ) for $1 \mathrm{~h}$ followed by treatment with or without LPS $(10 \mu \mathrm{g} / \mathrm{ml})$ for an additional 20 h. $n=3, \mathrm{~A}, \mathrm{~B}$ and C indicate significance $(P<0.05$ by ANOVA). 

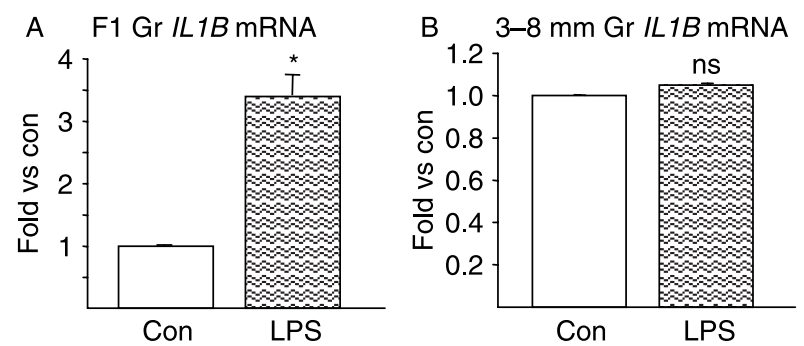

Figure 6 ILIB mRNA expression in granulosa cells following treatment with LPS. (A) Differentiated granulosa cells (from F1 follicles) were treated with or without LPS $(10 \mu \mathrm{g} / \mathrm{ml})$ for $4 \mathrm{~h} . n=3 *$ indicates significance $(P<0.05)$ by $t$-test. (B) Undifferentiated granulosa cells (from follicles 3-8 mm in diameter) were treated with or without LPS $(10 \mu \mathrm{g} / \mathrm{ml})$ for $20 \mathrm{~h} . n=3$, not significant (ns) $P>0.05$ by $t$-test.

maturation (Calvo et al. 1981, Johnson et al. 1996). It is also consistent with a recent report demonstrating gonadotropin stimulated TLRs in murine granulosa cells (Shimada et al. 2006). Significantly, this differential sensitivity suggests that TLR-signaling may modulate ovarian function specifically at the preovulatory stage, while providing protective mechanism against infection in follicles prior to selection. Notably, in undifferentiated granulosa cells from 3 to $8 \mathrm{~mm}$ follicles, treatment with LPS did not up-regulate TLR2 mRNA and resulted in the down-regulation of TLR4 mRNA.

The ability of LPS to modulate steroid production in hen granulosa cells is also stage dependent. In undifferentiated granulosa cells, treatment with LPS for $20 \mathrm{~h}$ abrogated $\mathrm{FSH}$-induced progesterone production. Furthermore, pre-treatment with U0126 prevented this decrease in progesterone, indicating that the actions of LPS on progesterone production are dependent upon downstream MAPK signaling. However, under similar conditions, LPS did not modulate the level of progesterone produced in response to $\mathrm{LH}$ or 8 -br-cAMP in differentiated granulosa cells from F2 or F1 follicles. Together, these findings are congruous with previously reported data revealing that the effects of MAPK on progesterone production in the hen are stage dependent (Woods et al. 2007). Moreover, accruing evidence from both mammalian and avian ovarian models indicate that the actions of $\mathrm{LH}$ are dependent upon MAPK signaling (Su et al. 2002, Park et al. 2004, Jammongjit et al. 2005, Woods et al. 2007). Thus, while TLR-induced MAPK signaling may be inhibitory in undifferentiated granulosa cells, there is precedence that it may transition to facilitory at the preovulatory stage. Concomitantly, the abrogation of gonadotropin-induced progesterone production in hen granulosa cells may represent an inherent mechanism to potentially block a follicle from being selected into the preovulatory hierarchy. Such a mechanism could contribute to the prevention of transovarian transmission of $S$. serovar spp. This mechanism may be of importance, as $S$. enteritidis has been demonstrated to preferentially invade prehierarchal follicles (Howard et al. 2005).

In addition to the differentiation-dependent effects of LPS-induced MAPK activity, LPS-induced cell death is also varied based upon stage of maturation. Whereas a significant decrease in cell viability was measured following treatment with $10 \mu \mathrm{g} / \mathrm{ml}$ LPS in differentiated granulosa cells, undifferentiated granulosa cells are more sensitive, undergoing apoptosis following $5 \mu \mathrm{g} / \mathrm{ml}$ LPS. Additionally, pre-treatment with the caspase-8 inhibitor, Z-IETD-FMK, only partially reversed LPS-induced cell death in undifferentiated granulosa cells while fully reversing the effects of LPS on cell death in differentiated granulosa cells. These data are consistent with numerous studies demonstrating that undifferentiated granulosa cells are inherently more sensitive to death than their differentiated counterparts (reviewed in Johnson 2000). This sensitivity has been attributed to elevated levels of pro-apoptotic proteins and reduced levels of antiapoptotic proteins (reviewed in Johnson 2000), reduced levels of the anti-apoptotic AKT (Johnson et al. 2001), and relatively rapid rate of proliferation (Woods et al. 2005). Moreover, these data further support a role for a TLR-mediated immune response in attenuation of transovarian transmission of $S$. enteritidis at the preselection stage of follicle maturation, whereas latter stages of development appear much less affected.

The ability of the caspase- 8 inhibitor to prevent the effects of LPS on viability in differentiated follicles indicates a requirement for the extrinsic cell death pathway, likely involving the up-regulation of one or more cytokines, or alterations in intracellular adaptor and executioner genes. Many of the chicken intracellular adaptor and executioner genes required for extrinsic cell death have recently been identified (Johnson et al. 2007), along with orthologous chicken death-inducting cytokine genes, including TNFSF10, TNFSF15, and ILIB. To date, the chicken ortholog to mammalian TNF has not been identified, and it has been proposed that TNFSF15 fulfills this role in the chicken (Takimoto et al. 2005). Notably, ILIB mRNA was increased following treatment with LPS in undifferentiated granulosa, while levels of TNFSF10 and TNFSF15 mRNAs remained unchanged (data not shown). This is consistent with a recent report in which i.v. LPS increased ILIB mRNA in granulosa layers from hen preovulatory follicles (Subdei et al. 2007). While ILIB was the only cytokine found to be transcriptionally regulated following stimulation with LPS in either study, these data do not preclude additional mediators of LPS-induced cell death. Rather, these data are indicative of a complete and fully functional TLRsignaling pathway in hen granulosa cells, with ILIB as an indicator of downstream transcriptional activation.

The reported decrease in TLR4 mRNA expression together with the impediment of gonadotropin-induced progesterone production and viability in undifferentiated granulosa cells is consistent with immune cell function. 
Down-regulation of TLR4 expression following LPS stimulation represents a critical component of LPS tolerance. Functionally, this process serves to prevent excessive inflammation (Ziegler-Heitbrock 1995). This prevention of inflammation may mechanistically lead to the destruction of only infected follicles without excessive cytokine production that could potentially target neighboring healthy follicles. While not entirely effective at preventing transovarian transmission of S. enteritidis, this mechanism may assist in the prevention of debilitating infertility in the face of infection.

Alternatively, given the up-regulation of TLRs in preovulatory follicle granulosa cells in response to LPS or gonadotropin, coupled with a lack of attenuation of steroidogenesis, it is possible that TLR signaling may mediate physiological processes at or around the time of ovulation. In fact, multiple endogenous ligands for TLRs have been reported (Zhang \& Schluesener 2006), many of which are present in hen ovarian follicles. These include hyaluronan fragments, fibronectin, and heparan sulfate. Of these, hyaluronan fragments and fibronectin are most highly expressed in the F1 follicle (Jackson et al. 1991, Asem \& Novero 1994), thus have the potential to activate TLRs at or around the time of ovulation. Notably, fibronectin is produced by hen granulosa cells in response to $\mathrm{LH}$ and epidermal growth factor (EGF; Asem \& Novero 1994, Asem \& Conkright 1995), which are requisite for ovulation and steroid production in preovulatory follicles (Bahr \& Johnson 1984, Woods et al. 2007). In murine granulosa cells, TLRs have been shown to bind hyaluronan fragments (Shimada et al. 2006). Hyaluronan is endogenously synthesized, forming part of the matrix required for cumulus expansion in preovulatory murine follicles (Eppig 1979). Interestingly, hyaluronan production has been shown to significantly increase in cultured rat ovarian cells following treatment with ILIB (Kokia et al. 1993), which shown herein is significantly up-regulated in preovulatory follicles in response to TLR-signaling.

In summary, these data demonstrate a functional TLR signaling cascade within hen ovarian granulosa cells. Activation of TLR signaling results in stage of maturationdependent effects on steroidogenesis, granulosa cell apoptosis, and cytokine production. In particular, these findings support a putative mechanism by which TLR signaling could modulate ovarian function, independently from pathogenic stimuli, in the latter stages of follicle maturation. The inflammatory-like response associated with ovulation includes extensive tissue remodeling occurring at and around the time of follicle rupture. TLRs may play a role in tissue remodeling (Zhang \& Schluesener 2006), thus contributing to structural changes occurring in the ovary due to ovulation (Girling \& Hedger 2007). While additional studies are required to determine what, if any, effects impacting follicle development are mediated through TLR signaling in granulosa cells in vivo, effects of both microorganisms as well as endogenously produced ligands have the potential to mediate ovarian function through TLRs expressed on granulosa cells.

\section{Materials and Methods}

\section{Animals and reagents}

Single-comb white leghorn hens (Creighton Bros., Warsaw, IN, USA), 25-40 weeks of age and laying regular sequences of, at minimum, six eggs, were used in all studies described. Birds were housed in individual laying batteries, with free access to feed (Purina Layena Mash, Purina Mills, St Louis, MO, USA) and water, and were exposed to a photoperiod of $15 \mathrm{~h}$ light:9 h darkness. Individual laying cycles were monitored by the daily timing of oviposition. Hens were euthanized 16-18 h prior to a mid-sequence ovulation by cervical dislocation. All procedures described herein were reviewed and approved by the University of Notre Dame Institutional Animal Care and Use Committee, and were performed in accordance with the Guiding Principles for the Care and Use of Laboratory Animals.

Tissues collected for cell culture and isolation of total RNA included bone marrow and ovarian granulosa cells from the largest (F1) preovulatory follicle, second largest (F2) preovulatory follicle, and granulosa cells from prehierarchal (prior to selection into the preovulatory hierarchy) follicles $3-8 \mathrm{~mm}$ in diameter. For cell culture experiments, granulosa cells were collected and dispersed as described previously (Tilly et al. 1991, Johnson \& Bridgham 2001). Cells were incubated for up to $6 \mathrm{~h}$ at $40^{\circ} \mathrm{C}$ in $12 \times 75 \mathrm{~mm}$ polypropylene tubes at a density of $5 \times 10^{5}$, or for $20 \mathrm{~h}$ in 6- or 96-well polystyrene culture dishes (Thermo Fisher Scientific, Rockford, IL, USA) at a density of $1 \times 10^{6}$ and $1.5 \times 10^{4}$ respectively in DMEM (Invitrogen), containing $2.5 \%$ FBS (Invitrogen), $0.1 \mathrm{mM}$ non-essential amino acids, and $1 \%$ antibiotic-antimycotic mixture (Invitrogen). All time points were evaluated based on previously established endpoints for granulosa cell function and viability (Tilly \& Johnson 1988, Johnson \& Bridgham 2001). Recombinant human FSH and ovine LH were provided by the National Hormone and Pituitary Program (HUMC, Torrance, CA, USA). The cAMP agonist, 8-br-cAMP, and the purified $S$. enteritidis LPS were from Sigma-Aldrich. U0126 (a selective MAPK extracellular signaling-regulated kinase (MAPK1) kinase (MAP3K2) inhibitor) was purchased from BioMol (Plymouth Meeting, PA, USA), while the caspase-8 inhibitor, Z-IETD-FMK, was from R\&D Systems (Minneapolis, MN, USA).

\section{PCR amplification of TLR adaptor and signaling components}

In an initial effort to verify a functional TLR signaling pathway in granulosa cells, Gallus orthologs of mammalian TLR2 (type 2), TLR4, and TLR15 were amplified from RT RNA (RT system, Promega) isolated from freshly collected granulosa cells (3-8 mm diameter or F1 follicles), as well as bone marrow. Additionally, intracellular signaling components and cytokines were amplified to verify the presence or absence in ovarian granulosa cells. Accession numbers and PCR primer pairs 
Table 1 PCR primer pairs for TLRs and related signaling components and downstream transcriptional targets.

\begin{tabular}{|c|c|c|c|c|}
\hline Gene name & Accession no. & Primers & Size & Annealing temperature $\left({ }^{\circ} \mathrm{C}\right)$ \\
\hline TRAF6 & XP_421089 & $\begin{array}{l}\text { GCAAAGATGGAGACGCAAAACACTC } \\
\text { ATTAGCACACCGCTGAGCACTTGG }\end{array}$ & 264 & 56.5 \\
\hline TOLLIP & NP_001006471 & $\begin{array}{l}\text { AACCCCCACAGCACATAATGGAGC } \\
\text { TTCCTTCTTTGTCATCACCCTGCC }\end{array}$ & 233 & 56 \\
\hline MAP $3 K 7$ & XP_001233504 & $\begin{array}{l}\text { GGTGTTTACAGTGTTCCCAAGGAG } \\
\text { TTCAGGTGCCATCCAAGCAG }\end{array}$ & 203 & 54.2 \\
\hline МАРЗКIP1 & XP_416787 & $\begin{array}{l}\text { TTGAACCACCGCAAAGACCTGG } \\
\text { TGGCTGAGATACCATTACCCGAGG }\end{array}$ & 248 & 56.7 \\
\hline MAPЗКIP2 & XP_419660 & $\begin{array}{l}\text { CAGTTTCTCCAAATAAGCССССТGC } \\
\text { AGTTCTCGTTGAAGTCGCTCСАTCC }\end{array}$ & 253 & 57 \\
\hline МАР $3 К 14$ & NP_001026098 & $\begin{array}{l}\text { GGAAGAATACTTGGTGGACGCCTTG } \\
\text { CGCACTGAAATCCTGTCTGCTTGTC }\end{array}$ & 281 & 59.3 \\
\hline LY96 & XP_001232093 & $\begin{array}{l}\text { TCCTGGAGTCAGTGGATTTTTCTG } \\
\text { GCAATGCTCTGGCACCTTCATAC }\end{array}$ & 215 & 53.6 \\
\hline CD14 & XP_001232016 & $\begin{array}{l}\text { GACTTCCCCATCCTCATCCG } \\
\text { CACACСTTGCСТTTCACAATGTTC }\end{array}$ & 152 & 57.2 \\
\hline MAL/TIRAP & NP_001020000 & $\begin{array}{l}\text { TTTССТССТССТССТСТGСТTG } \\
\text { АТССТТССТGТСААТGТССТTСАG }\end{array}$ & 422 & 60.2 \\
\hline IRAK4 & NP_001025909 & $\begin{array}{l}\text { GGCATTGTGTTCAAAGGCTACATC } \\
\text { CAAGCAAGTCTGTCAAGCAGCG }\end{array}$ & 236 & 54.2 \\
\hline IRAK2 & NP_001025776 & $\begin{array}{l}\text { TTCACTTCCTTCTCCACCACCTC } \\
\text { TGTTGTGCCTCTGACCTTTGTAGC }\end{array}$ & 251 & 55.7 \\
\hline TLR4 & NM_001030693 & $\begin{array}{l}\text { CTACTTTGATGATTGCСТTCСТCC } \\
\text { AATAGTTCTGGACСTTCACTCTCСС }\end{array}$ & 287 & 56.7 \\
\hline TLR2 & NM_204278 & $\begin{array}{l}\text { GATTGTGGACAACATCATTGACTC } \\
\text { AACGCTGCTTTCAAGTTTTCCC }\end{array}$ & 294 & 55.4 \\
\hline TLR15 & NM_001037835 & $\begin{array}{l}\text { GTTCTCTCTCCCAGTTTTGTAAATAGC } \\
\text { GTGGTTCATTGGTTGTTTTTAGGAC }\end{array}$ & 262 & 55.1 \\
\hline TNFSF15 & NM_001024578 & $\begin{array}{l}\text { CCTGAGTTATTCCAGCAACGCA } \\
\text { ATCCACGAGCTTGATGTCACTAAC }\end{array}$ & 292 & 55.9 \\
\hline TNFSF10 & AB114678 & $\begin{array}{l}\text { CAAAGACAGAGTGGCTGACCCC } \\
\text { ATTCGTTCCAACAAACCCGAG }\end{array}$ & 417 & 58.1 \\
\hline$I L I B$ & NM_204524 & $\begin{array}{l}\text { CACAGAGATGGCGTTCGTTCC } \\
\text { AGGTGACGGGCTCAAAAACC }\end{array}$ & 293 & 56.8 \\
\hline MYD88 & NM_0001030962 & $\begin{array}{l}\text { GAAAGACCTTCAGTTTGTCCAGGAG } \\
\text { AGATGCTGTAGGAACACCGTGG }\end{array}$ & 458 & 56.4 \\
\hline
\end{tabular}

specific for Gallus TLRs and signaling components are listed in Table 1. While PCR conditions were specific for primer pairs, amplification conditions included an initial denaturing for 3 min at $94{ }^{\circ} \mathrm{C}$, followed by 40 cycles of denaturing at $94{ }^{\circ} \mathrm{C}$ (45 s), annealing at $51-62{ }^{\circ} \mathrm{C}(45 \mathrm{~s})$, followed by an extension step at $72{ }^{\circ} \mathrm{C}(60 \mathrm{~s})$ using Taq DNA polymerase (Invitrogen). All PCR products were subsequently sequenced to verify nucleic acid identity.

\section{Progesterone analysis}

Progesterone in cell culture medium samples was measured by RIA as previously described (Tilly \& Johnson 1988). The replicate experiments were combined, and the mean ( \pm s.E.M.) values are expressed as fold difference versus control (untreated) cells.

\section{Quantitative (real-time) PCR}

Forward and reverse primers encoding type 2 TLR2, TLR4, ILIB and $18 \mathrm{~s}$ rRNA (used for standardization) were generated using MacVector software (Table 1), and were subsequently validated for use with real-time PCR by determining the optimal amplification efficiency and primer conditions as described by the system manufacturer (Applied Biosystems, Foster city, CA, USA). Random-primed, RT cDNA synthesis reactions were performed using the Promega Reverse Transcription System (Promega), according to conditions described by the manufacturer. Template dilutions were performed to verify that amplification efficiency of TLR2, TLR4, ILIB was the same as that of the $18 \mathrm{~s}$ rRNA housekeeping gene. For real-time PCR, primers were added to $25 \mu$ total reaction volume using reagents provided in the ABgene Absolute QPCR Sybr Green Mix (ABgene, Epsom, UK). Reactions were completed on the ABI 7700 Thermocycler (Applied Biosystems). Amplification conditions included an initial denaturing for 15 min at $95^{\circ} \mathrm{C}$ followed by 15 -s denaturing at $95{ }^{\circ} \mathrm{C}, 1 \mathrm{~min}$ annealing at $60{ }^{\circ} \mathrm{C}$ and $1 \mathrm{~min}$ extension at $72{ }^{\circ} \mathrm{C}$ for 40 cycles. The $C_{\mathrm{t}}$ (defined as the cycle number at which the fluorescence exceeds a threshold level) was determined for each reaction (run in triplicate) using the Sequence Detection software (v.1.6.3), while quantification was accomplished using the $\Delta \Delta C_{\mathrm{t}}$ method (Livak \& Schmittgen 2001).

\section{Cell density assays}

Immediately following collection, $1.5 \times 10^{4}$ cells/well were seeded into a 96 -well plate. Cells were treated in the presence or absence of LPS (1-10 $\mu$ g) for $24 \mathrm{~h}$. All treatments in each replicate experiment were performed in triplicate. Cell density 
was monitored using the colorimetric CellTiter 96 Aqueous One Solution Cell Proliferation Assay (Promega), as a measure of metabolic activity and viability. The indicator solution was added directly to the plate after $24 \mathrm{~h}$ culture, incubated for an additional $1-4 \mathrm{~h}$, and the absorbance values were read at $490 \mathrm{~nm}$. Where applicable, the caspase-8 inhibitor, Z-IETD-FMK, was added $1 \mathrm{~h}$ prior to the addition of LPS. Apoptosis was verified through the qualitative analysis of oligonucleosome formation as described previously (Johnson et al. 1998).

\section{Data analysis}

Experiments were independently replicated a minimum of three times unless otherwise specified. Standardized values for the combined replicate experiments were expressed as a fold difference (mean \pm s.E.M.) versus control cultured cells. Data were analyzed by one-way ANOVA without including data from the control group (arbitrarily set to 1.0), followed by Fisher's protected least significant multiple range test for post hoc analysis. In instances where a $t$-test was used to compare two related treatments, individual comparisons were made using original, non-transformed, data.

\section{Declaration of interest}

The authors D C W, J S S, and A L J have nothing to declare related to the material being published.

\section{Funding}

This work was supported by National Research Initiative Competitive Grant no. 2007-35203-18085 from the USDA Cooperative State Research, Education, and Extension Service.

\section{Acknowledgements}

We thank Martin Vonau and Morgan J Haugen for their excellent technical assistance.

\section{References}

Asem EK \& Conkright MD 1995 Role of progesterone in luteinizing hormone-induced fibronectin production and deposition by chicken granulosa cells in vitro. Comparative Biochemistry and Physiology. Part C, Pharmacology, Toxicology \& Endocrinology 112 247-255.

Asem EK \& Novero RP 1994 Stimulation of fibronectin production and deposition by chicken granulosa cells in vitro by epidermal growth factor and transforming growth factor alpha. Journal of Reproduction and Fertility 101 374-384.

Bahr JM \& Johnson AL 1984 Regulation of the follicular hierarchy and ovulation. Journal of Experimental Zoology 232 495-500.

Braden CR 2006 Salmonella enterica serotype enteritidis and eggs: a national epidemic in the United States. Clinical Infectious Diseases 43 $512-517$.

Calvo FO, Wang SC \& Bahr JM 1981 LH-stimulable adenylyl cyclase activity during the ovulatory cycle in granulosa cells of the three largest follicles and the postovulatory follicle of the domestic hen (Gallus domesticus). Biology of Reproduction 25 805-812.
Eppig JJ 1979 FSH stimulates hyaluronic acid synthesis by oocyte-cumulus cell complexes from mouse preovulatory follicles. Nature 281 483-484.

Fukui A, Inoue N, Matsumoto M, Nomura M, Yamada K, Matsuda Y, Toyoshima K \& Seya T 2001 Molecular cloning and functional characterization of chicken toll-like receptors. A single chicken toll covers multiple molecular patterns. Journal of Biological Chemistry 276 47143-47149.

Gast RK \& Beard CW 1990 Isolation of Salmonella enteritidis from internal organs of experimentally infected hens. Avian Diseases 34 991-993.

Girling JE \& Hedger MP 2007 Toll-like receptors in the gonads and reproductive tract: emerging roles in reproductive physiology and pathology. Immunology and Cell Biology 85 481-489.

Herath S, Williams EJ, Lilly ST, Gilbert RO, Dobson H, Bryant CE \& Sheldon IM 2007 Ovarian follicular cells have innate immune capabilities that modulate their endocrine function. Reproduction 134 683-693.

Howard ZR, Moore RW, Zabala-Diaz IB, Landers KL, Byrd JA, Kubena LF, Nisbet DJ, Birkhold SG \& Ricke SC 2005 Ovarian laying hen follicular maturation and in vitro Salmonella internalization. Veterinary Microbiology 108 95-100.

Iqbal M, Philbin VJ, Withanage GS, Wigley P, Beal RK, Goodchild MJ, Barrow P, McConnell I, Maskell DJ, Young J et al. 2005 Identification and functional characterization of chicken toll-like receptor 5 reveals a fundamental role in the biology of infection with Salmonella enterica serovar typhimurium. Infection and Immunity 73 2344-2350.

Jackson JA, Friberg AC \& Bahr JM 1991 Preovulatory changes in glycosaminoglycans and collagen content in the stigma region of the follicle of the domestic hen. Biology of Reproduction 45 301-307.

Jammongjit M, Gill A \& Hammes SR 2005 Epidermal growth factor receptor signaling is required for normal ovarian steroidogenesis and oocyte maturation. PNAS 102 16257-16262.

Johnson AL 2000 Granulosa cell apoptosis: conservation of cell signaling in an avian ovarian model system. Biological Signals and Receptors 9 96-101.

Johnson AL \& Bridgham JT 2001 Regulation of steroid acute regulatory protein and luteinizing hormone receptor messenger ribonucleic acid in hen granulosa cells. Endocrinology 142 3116-3124.

Johnson AL, Bridgham JT \& Wagner B 1996 Characterization of a chicken luteinizing hormone receptor (cLH-R) complementary deoxyribonucleic acid, and expression of CLH-R messenger ribonucleic acid in the ovary. Biology of Reproduction 55 304-309.

Johnson AL, Bridgham JT, Munks M \& Witty JP 1998 Characterization of the chicken interleukin-1 beta converting enzyme (caspase-1) cDNA and expression of caspase-1 mRNA in the hen. Gene 219 55-62.

Johnson AL, Bridgham JT \& Swenson JA 2001 Activation of the Akt/protein kinase B signaling pathway is associated with granulosa cell survival. Biology of Reproduction 64 1566-1574.

Johnson AL, Ratajczak C, Haugen MJ, Liu HK \& Woods DC 2007 Tumor necrosis factor-related apoptosis inducing ligand expression and activity in hen granulosa cells. Reproduction 133 609-616.

Kokia E, Hurwitz A, Ben-Shlomo I, Adashi EY \& Yanagishita M 1993 Receptor-mediated stimulatory effect of IL-1 beta on hyaluronic acid and proteoglycan biosynthesis by cultured rat ovarian cells: role for heterologous cell-cell interactions. Endocrinology 133 609-616.

Leveque G, Forgetta V, Morroll S, Smith AL, Bumstead N, Barrow P, Loredo-Osti JC, Morgan K \& Malo D 2003 Allelic variation in TLR4 is linked to susceptibility to Salmonella enterica serovar typhimurium infection in chickens. Infection and Immunity 71 1116-1124.

Liu Z, Shimada M \& Richards JS 2008 The involvement of the toll-like receptor family in ovulation. Journal of Assisted Reproduction and Genetics 25 223-228.

Livak KJ \& Schmittgen TD 2001 Analysis of relative gene expression data using real-time quantitative PCR and the $2^{-C_{t}}$ method. Methods 25 402-408.

Lynn DJ, Lloyd AT \& O'Farrelly C 2003 In silico identification of components of the toll-like receptor (TLR) signaling pathway in clustered chicken expressed sequence tags (ESTs). Veterinary Immunology and Immunopathology 93 177-184.

Medzhitov R, Preston-Hurlburt P \& Janeway CA Jr 1997 A human homologue of the Drosophila toll protein signals activation of adaptive immunity. Nature 388 394-397. 
Park JY, Su YQ, Ariga M, Law E, Jin SL \& Conti M 2004 EGF-like growth factors as mediators of LH action in the ovulatory follicle. Science $\mathbf{3 0 3}$ 682-684.

Philbin V, Iqbal JM, Boyd Y, Goodchild MJ, Beal RK, Bumstead N, Young J \& Smith AL 2005 Identification and characterization of a functional, alternatively spliced toll-like receptor 7 (TLR7) and genomic disruption of TLR8 in chickens. Immunology 114 507-521.

Shimada M, Hernandez-Gonzalez I, Gonzalez-Robanya I \& Richards JS 2006 Induced expression of pattern recognition receptors in cumulus oocyte complexes: novel evidence for innate immune-like functions during ovulation. Molecular Endocrinology 20 3228-3239.

Shimada M, Yanai Y, Okazaki T, Noma N, Kawashima I, Mori T \& Richards JS 2008 Hyaluronan fragments generated by sperm-secreted hyaluronidase stimulate cytokine/chemokine production via the TLR2 and TLR4 pathway in cumulus cells of ovulated COCs, which may enhance fertilization. Development 135 2001-2011.

Spiller S, Dreher S, Meng G, Hochrein A, Brade H, Bessler W, Wagner H, Carsten J \& Kirschning J 2007 Cellular recognition of trimyristoylated peptide or enterobacterial lipopolysaccharide via both TLR2 and TLR4. Journal of Biological Chemistry 282 13190-13198.

Su YQ, Wigglesworth K, Pendola FL, O'Brien MJ \& Eppig JJ 2002 Mitogenactivated protein kinase activity in cumulus cells is essential for gonadotropin-induced oocyte meiotic resumption and cumulus expansion in the mouse. Endocrinology 143 2221-2232.

Subdei K, Isobe N, Nishibori M \& Yoshimura Y 2007 Changes in the expression of toll-like receptor mRNAs during follicular growth and in response to lipopolysaccharide in the ovarian follicles of laying hens. Journal of Reproduction and Development 53 1227-1235.

Takeda K \& Akira S 2005 Toll-like receptors in innate immunity. International Immunology 17 1-14.

Takimoto T, Takahashi K, Sato K \& Akiba Y 2005 Molecular cloning and functional characterizations of chicken TL1A. Developmental and Comparative Immunology 29 895-905.
Temperly ND, Berlin SB, Paton IR, Griffen DK \& Burt DW 2008 Evolution of the chicken toll-like receptor gene family: a story of gene gain and gene loss. BMC Genomics 962.

Thiagarajan D, Saeed AM \& Asem EK 1994 Mechanism of transovarian transmission of Salmonella enteritidis in laying hens. Poultry Science $\mathbf{7 3}$ 89-98.

Tilly JL \& Johnson AL 1988 Attenuation of hen granulosa cell steroidogenesis by a phorbol ester and 1-oleoyl-2-acetylglycerol. Biology of Reproduction 38 1-8.

Tilly JL, Kowalski KI \& Johnson AL 1991 Stage of ovarian follicular development associated with the initiation of steroidogenic competence in avian granulosa cells. Biology of Reproduction 44 305-314.

Woods DC, Haugen MJ \& Johnson AL 2005 Opposing actions of TGFbeta and MAP kinase signaling in undifferentiated hen granulosa cells. Biochemical and Biophysical Research Communications 336 450-457.

Woods DC, Haugen MJ \& Johnson AL 2007 Actions of epidermal growth factor receptor/mitogen-activated protein kinase and protein kinase C signaling in granulosa cells from Gallus gallus are dependent upon stage of differentiation. Biology of Reproduction 77 61-70.

Zhang Z \& Schluesener HJ 2006 Mammalian toll-like receptors: from endogenous ligands to tissue regeneration. Cellular and Molecular Life Sciences 63 2901-2907.

Ziegler-Heitbrock HW 1995 Molecular mechanism in tolerance to lipopolysaccharide. Journal of Inflammation 45 13-26.

Received 29 July 2008

First decision 18 September 2008

Revised manuscript received 18 February 2009

Accepted 30 March 2009 